\title{
MYCOTAXON
}

\section{A new species of Scopinella from pampas grass in Argentina}

\author{
ROMINA M. SÁNCHEZ, LUCRECIA GIORDANO, FREDA E. ANDERSON \& M. \\ VIRGINIA BIANCHINOTTI* \\ Centro de Recursos Naturales Renovables de la Zona Semiárida-Universidad Nacional del Sur \\ Camino La Carrindanga Km 7, B8000FWB, Bahía Blanca, Argentina \\ *CORRESPONDENCE TO: vbianchi@uns.edu.ar
}

\begin{abstract}
A previously undescribed species of the genus Scopinella was found during a survey of the fungi associated with Cortaderia selloana (Poaceae) in Argentina. The ascospores are strongly asymmetrical and have the shape of a truncated pyramid with a convex quadrangular base. This peculiar ascospore shape sets this species apart from the others of the genus and is therefore described here as new. This is the second record of the genus from South America.
\end{abstract}

KEY WORDS - ascomycete, grasses, saprophytic fungi

\section{Introduction}

Cortaderia selloana (pampas grass) is a perennial tussock-forming grass species that is native to Argentina, Brazil, Chile, Paraguay and Uruguay (Astegiano et al. 1995). Its huge tussocks are very conspicuous and become attractive when they flower to produce showy feathery inflorescences. It has been introduced in many regions of the world as a garden plant, for dryland forage, soil amendment, and as windbreaks. In some of these, it has become invasive (Pausas et al. 2006). In particular, it has become a serious weed in New Zealand, where the feasibility of conducting biological control is being explored (Bellgard et al. 2010).

Most of the records of fungal species found associated with $C$. selloana are the result of studies performed in the countries where it has been introduced (Bellgard et al. 2010, Farr \& Rossman 2012, McKenzie et al. 2007, Medd et al. 2003). Studies are now being conducted in Argentina to learn about the associated mycobiota present in its native distribution area.

During a survey of the fungi associated with C. selloana leaves in Buenos Aires province, a new species of the genus Scopinella Lév. was discovered. 
The genus Scopinella is characterized by ascomata with long necks and globose bodies, evanescent asci, and cuboid-ellipsoidal ascospores with two prominent longitudinal germ slits (Cannon \& Hawksworth 1982, Stchigel et al. 2006). It is a small genus that comprises seven species that grow either on fungi or plant substrates. It belongs to Hypocreales, where at present it cannot be assigned to any family (Lumbsch \& Huhndorf 2010).

The shape of the ascospores of the specimen found on C. selloana distinguishes it from the other species of the genus, so we describe it here as new.

\section{Materials \& methods}

Partially senescent leaves of Cortaderia selloana were carefully inspected under a Wild M5A stereomicroscope. Sections bearing fruiting bodies were hand-made with a razor blade and mounted in either distilled water alone or with the addition of phloxine. Measurements were made in water. A Leica DM2000 dissecting microscope with a Leica EC3 camera was used to capture micromorphological images. For scanning electron microscopy intact ascomata were dehydrated in a graded acetone series from $10 \%$ to $90 \%$, and finally $95 \%$ for fifteen minutes in each step, followed by three changes in absolute acetone. After critical point-drying, the specimens were mounted on aluminum stubs, sputter coated with gold-palladium, and viewed with a LEO EVO 40 Scanning Electron Microscope (SEM). Recently collected leaves with the fungus were pressed and preserved in "Bahía Blanca Biología" Herbarium (BBB). Herbarium is abbreviated according to Thiers (2012).

Scopinella pyramidospora R.M. Sánchez, L. Giord., F. Anderson \& Bianchin., sp. nov. MYCoBANK MB800633

DiAGNOSIS: Differs from all other Scopinella species by its strongly asymmetrical, pyramidal ascospores.

TYPE: Argentina, Buenos Aires Province, Provincial Route No. 205, Km 308, $\left(36^{\circ} 06^{\prime} 43^{\prime \prime} \mathrm{S} 60^{\circ} 58^{\prime} 22^{\prime \prime} \mathrm{W}\right)$ : on senescent leaves of Cortaderia selloana (Schult. \& Schult. f.) Asch. \& Graebn. (Poaceae), 4.VII.2011, coll. FE Anderson (HOLOTYPE, BBB [MVB 1501]).

ETYMOLOGY: from the Greek $\pi v \rho \alpha \mu i ́ \delta o \varsigma=$ pyramidal and $\sigma \pi$ ópos: spore.

AsCOMATA solitary to gregarious, superficial, settled on a dense mass of brown hyphae, globose to subglobose, with long necks, brown to black when dry, brown to paler brown at base when mounted in water, 106-150 $\mu \mathrm{m}$ high, 106-225 $\mu \mathrm{m}$ wide, peridial cells forming textura intricata. NECKS cylindrical, 206-313 $\mu \mathrm{m}$ long, 31-75 $\mu \mathrm{m}$ wide at base, ostiolum 19-38 $\mu \mathrm{m}$ wide, cells of neck disposed in textura porrecta. PARAPHYSES moniliform, ramified, septate, hyaline, 4-7 $\mu \mathrm{m}$ wide. ASCI 8-spored, unitunicate, clavate to globose, shortstipitate, evanescent, 13-28 $\times 10-16 \mu \mathrm{m}$. ASCOSPORES 1-celled, strongly 
asymmetrical, resembling a truncated pyramid with quadrangular, somewhat convex, base, rounded vertices, smooth-walled at optical level, verruculose under SEM $(>7,000 \times)$ with a dark brown median band, paler at ends, germ slits occasionally present, $7.5-9.5 \times 5.5-8.5 \mu \mathrm{m}(x=8.4 \times 6.7, \mathrm{n}=60)$. ANAMORPH not known.

DisTRIBUTION - Argentina, known only from the type collection.

COMMENTS - Scopinella pyramidospora differs from all other species of the genus in having strongly asymmetrical, pyramidal ascospores. Ascospore asymmetry is best visualized by moving the microslide in three dimensions when mounted in water. Germ slits were seen only once under optical microscopy. This suggests that they are not as conspicuous and/or common as in the other species of the genus. Although the spore size falls in the range of S. caulincola (Fuckel) Malloch, ascospores of the latter are strongly flattened bilaterally and almost rectangular in surface view (as shown in von Arx \& Müller 1954). The ascomata of $S$. caulincola have much longer necks, up to $2 \mathrm{~mm}$ long, with subhyaline short bristles at the apex (fide von Arx \& Müller 1954). Ascomatal necks of S. pyramidospora are glabrous.

\section{Discussion}

The genus Scopinella was erected by Léveillé (1847) to accommodate the single species S. barbata (Pers.) Lév. Saccardo (1891) added a second species, S. pleiospora (J. Schröt.) Sacc., which had originally been described as Melanospora pleiospora. The genus was then ignored for almost a century until Hawksworth (1975) reestablished it by recognizing the synonymy between S. barbata and Chaetoceratostoma hispidum Turconi \& Maffei. Hawksworth (1975) considered Scopinella to be monospecific and did not include Saccardo's Scopinella pleiospora. Malloch $(1976 a, b)$ added three species to the genus ( $S$. caulincola, $S$. solani, and S. sphaerophila) and provided a key to differentiate these additions and the original $S$. barbata. Two more species were added, $S$. gallicola by Tsuneda \& Hiratsuka (1981) and $S$. musciformis by Stchigel et al. (2006). No reference was made to Scopinella pleiospora in any of these studies. We failed to access type or authenticated material, and presume the type material of $S$. pleiospora has been lost. 


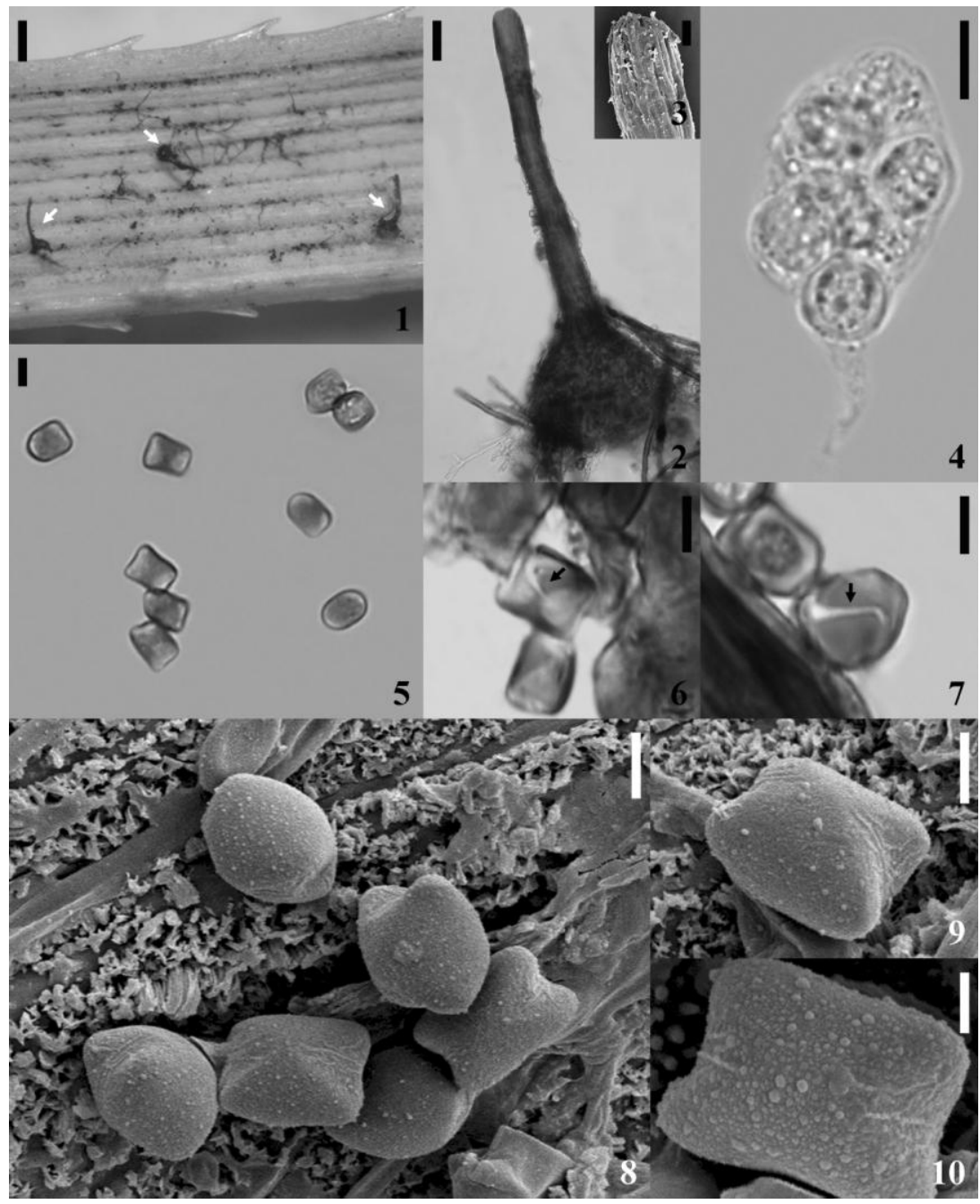

Plate 1: Scopinella pyramidospora: 1. Ascomata on the substrate (arrows). 2. Close-up of an ascoma. 3. Apex of the ascomata neck (SEM, 4500×). 4. Eight-spored ascus. 5. Asymmetrical ascospores in various views. 6, 7. Ascospore germ slits (arrows). 8. Ascospores (SEM, 7000x). 9. Lateral view of a pyramidal ascospore (SEM, 10000 $\times$ ). 10. Detail of ascospore wall (SEM, 20000x). Bars: $1=200 \mu \mathrm{m} ; 2=50 \mu \mathrm{m} ; 3=10 \mu \mathrm{m} ; 4,6,7=5 \mu \mathrm{m} ; 5=7 \mu \mathrm{m} ; 8=4 \mu \mathrm{m} ; 9=3$ $\mu \mathrm{m} ; 10=2 \mu \mathrm{m}$.

Species of Scopinella fall into two ecological groups. One comprises species growing on other fungi ( $S$. gallicola and $S$. sphaerophila), and the other saprobic species, usually growing on plant substrates ( $S$. barbata, $S$. caulincola, S. musciformis, S. pyramidospora, and S. solani). Scopinella pleiospora was described growing on rabbit dung. Scopinella pyramidospora and $S$. solani are the only two species of the genus known to occur on grasses. Scopinella solani was found growing on dead leaves of Poa nevadensis in North America (Malloch 1976a) and on overwintered 
inflorescences of Brachypodium pinnatum, Dactylis glomerata, and Elytrigia repens in Slovakia (Pastirčák \& Pastirčáková 2007). Scopinella solani differs from $S$. pyramidospora in having longer ascomatal necks $(300-500 \mu \mathrm{m})$, narrower asci $(7-11.5 \mu \mathrm{m})$, and symmetrical and smaller ascospores (4.5-6.5 $\times 3.8-5.8 \mu \mathrm{m})$.

Species of Scopinella are difficult to cultivate, and the species from Cortaderia selloana was no exception. All attempts to isolate it on artificial media failed. Because of this, and the fact that the available material is at present very scarce, it was decided against performing any molecular work. To our knowledge the only species that have been cultivated are $S$. gallicola (Tsuneda \& Hiratsuka 1981) and S. solani (Zhang \& Blackwell 2002). Tsuneda \& Hiratsuka (1982) found that for S. gallicola both growth and fructification were stimulated in dual culture with other fungi.

Phylogenetic studies have been performed on S. solani which is the only species that has been sequenced. Zhang \& Blackwell (2002) set it in a distinct clade in Hypocreales apart from Melanospora in contrast with what was previously accepted (Hawksworth 1975).

The genus Scopinella was reported in Argentina and South America for the first time with the finding of $S$. solani on bark of Geoffroea decorticans (Bianchinotti 1998). This is the second record of the genus from this region.

\section{Acknowledgments}

This work was funded by "National Biocontrol Collective" and "Future Forests Research", New Zealand. Lucrecia Giordano is a fellow at CIC. MVB is a researcher at CONICET. Amy Rossman and Alberto Stchigel are thanked for acting as presubmission reviewers and for their helpful comments.

\section{Literature cited}

Arx JA von, Müller E. 1954. Die Gattungen der amerosporen Pyrenomyceten. Beitr. Kryptfl. Schweiz 11 (1): 1-434.

Astegiano ME, Anton AM, Connor HE. 1995. Sinopsis del género Cortaderia (Poaceae) en Argentina. Darwiniana 33: 43-51.

Bellgard SE, Winks CJ, Than DJ, Aliaga CC. 2010. Natural enemies of the South American pampas grasses Cortaderia spp. in New Zealand. 215-218, in SM Zydenbos (ed.), Proceedings of the 17th Australasian Weeds Conference. New Zealand Plant Protection Society.

Bianchinotti MV. 1998. Contribución al conocimiento de la micobiota argentina. Micromicetes sobre Geoffroea decorticans (Leguminosae). III. Bol. Soc. Argent. Bot. 33: 149-155.

Cannon PF, Hawksworth DL. 1982. A re-evaluation of Melanospora Corda and similar Pyrenomycetes, with a revision of the British species. Bot. J. Linn. Soc. 84: 115-160. http://dx.doi.org/10.1111/j.1095-8339.1982.tb00363.x

Farr DF, Rossman AY. 2012. Fungal databases. Systematic Mycology and Microbiology Laboratory, ARS, USDA. http://nt.ars-grin.gov./fungaldatabases/ [accessed: 16 April 2012]. 
6_Mycotaxon MSWord Template and Styles Sheet 2012

Hawksworth DL. 1975. Chaetoceratostoma Turc. \& Maffei, a genus to be rejected. Trans. Brit. Mycol. Soc. 64: 447-453. http://dx.doi.org/10.1016/S0007-1536(75)80143-4

Léveillé DM. 1847. Mycologie, Mycétologie. 454-496, in: C Orbigny. Dictionnaire Universel d'Histoire Naturelle 8.

Lumbsch HT, Huhndorf SM. 2010. Part one. Outline of Ascomycota -2009. Myconet 14: 1-42.

Malloch D. 1976a. Scopinella solani. Fungi Canadenses 82.

Malloch D. 1976b. Scopinella sphaerophila. Fungi Canadenses 83.

McKenzie EHC, Thongkantha S, Lumyong S. 2007. Zygosporium bioblitzi sp. nov. on dead leaves of Cortaderia and Dracaena. N.Z. J. Bot. 45: 433-435. http://dx.doi.org/10.1080/00288250709509724

Medd RW, Murray GM, Pickering DI. 2003. Review of the epidemiology and economic importance of Pyrenophora semeniperda. Australas. Plant Pathol. 32: 539-550. http://dx.doi.org/10.1071/AP03059

Pastirčák M, Pastirčáková K. 2007. Scopinella solani on graminicolous hosts in Slovakia and the Czech Republic. Mycotaxon 102: 383-387.

Pausas JG, Lloret F, Vilá M. 2006. Simulating the effects of different disturbance regimes on Cortaderia selloana invasión. Biol. Conservation 128: 128-135. http://dx.doi.org/10.1016/j.biocon.2005.09.022

Saccardo PA. 1891. Supplementum universale, pars I. Sylloge Fungorum 9. 1141 p.

Stchigel AM, Umaña L, Guarro J, Mata M. 2006. Two new ascomycetes from rainforest litter in Costa Rica. Mycologia 98: 815-820. http://dx.doi.org/10.3852/mycologia.98.5.815

Thiers B. 2012 [continuously updated]. Index Herbariorum: a global directory of public herbaria and associated staff. New York Botanical Garden's Virtual Herbarium. http://sweetgum.nybg.org/ih/ [accessed: February 2012].

Tsuneda A, Hiratsuka Y. 1981. Scopinella gallicola, a new species from rust galls of Endocronartium harknessii on Pinus contorta. Canad. J. Bot. 59: 1192-1195. http://dx.doi.org/10.1139/b81-163

Tsuneda A, Hiratsuka Y. 1982. Commensal relationship between Scopinella gallicola and Cladosporium sp. Rept. Tottori Mycol. Inst. (Japan) 20: 63-69.

Zhang N, Blackwell M. 2002. Molecular phylogeny of Melanospora and similar pyrenomycetous fungi. Mycol. Res. 106: 148-155. 